\title{
個材の弾塑性座屈挙動を考慮したトラス梁に対する解析手法の提案

\author{
ANALYTICAL METHOD FOR TRUSS GIRDER INVOLVING MEMBER'S \\ ELASTOPLASTIC BUCKLING BEHAVIOR
}

\author{
元結 正次郎*，大塚 貴 弘** \\ Shojiro MOTOYUI and Takahiro OHTSUKA
}

\begin{abstract}
In analyzing a huge structure composed of truss girder, the method to substitute a beam element for truss girder is very useful. However, this method is not clear for the application to elastoplastic buckling behavior. We have already proposed a consistent and convenient method to analyze the elastoplastic buckling behavior of compression member. Then in this paper, we extend this method to truss girder and propose an analytical method for the effective continuous model which enables us to analyze the elastoplastic buckling behavior of truss girder involving chord member's buckling without constructing discrete model. The present method is formulated to satisfy the second law of thermodynamics. And we describe the validity of our method by comparing the numerical results of discrete model with ones of proposed continuous model.
\end{abstract}

Keywords: truss girder, elastoplastic buckling behavior, thermodynamics, plastic dissipation トラス梁、弾塑性座屈挙動、熱力学、塑性散逸

\section{1. はじめに}

トラス梁を平面的・立体的に配することにより大スパン構造を形 成することができるが、トラス構造物は構成部材の個材座屈により 全体の挙動が支配されることが多く、対象構造物の倒壊挙動を評価 するためには個材の座屈挙動を適切に評価することが必要である。

個材座屈を伴うトラス梁に関する研究については耐力に着目した 研究が数多くなされ、特に日置らは個材の弾性座屈に対して有効剛 性・有効強度の概念に基づく連続体的取扱いによりラチス椪造の力 学的性状を巨視的に把晎する手法 "を提案している。また、座屈後 の挙動に関して上谷らは弾性剛節トラスに対する連続体置換法を用

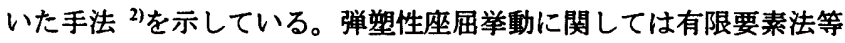
の離散化手法あるいは数值解析的取扱いを比較的简便にしたものと

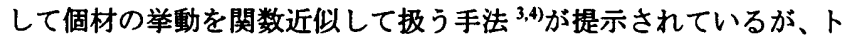
ラス梁で樓成される大規模構造物は部材数が膨大となることから有 奻な手段とは言い難い。

一方、局部的な座屈を考虑した簡便な梁柱部材モデルとして特に、

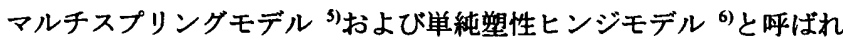
る手法が提案されている。これらのモデルは部材としての復元力特 性に局部的な座屈の影響を反映させてはいるものの、そこで用いら れている設定条件や力学的背景に関して曖昧な点を有している。 これに対し、トラス梁を 1 要素として解析する手法 (縮合モデル)
は部材数の低減による解析上の有利さのみならず、設計対象となる 架構の力学的特性の把握という点からも有効な解析手段であり、著 者らは文献 11)において個材が塑性化する場合のトラス梁の弾塑性 挙動に対して、塑性論に基つく緍合モデルを用いた解析手法を提案 しているが、座届に対して塑性論の適用は一般化されていない。 そこで、本論文ではより基本的な考えである熱力学に基づき文献 12)において著者らが提案したトラス材の弾塑性座屈挙動に対する 評価手法を㹡張し、Fig.1 に示すワーレン型トラス梁における弾塑性 挙動に対して、個材座屈を考虑した縮合モデルを用いる解析手法を 提案することを目的としている。また、提案手法に対する具体的な 応力算定手順を示し、縮合モデルと離散化モデルを用いた数值解析 結果を比較することにより、本手法の妥当性について検証している。
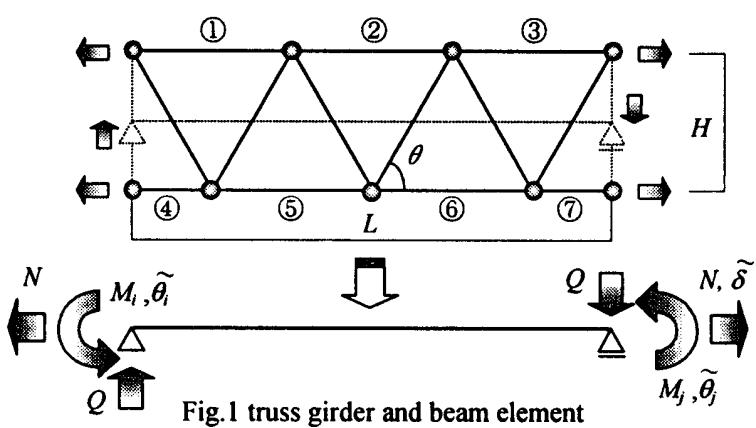

* 東京工業大学大学院人間環境システム専攻 助教授・工博

** 東京工業大学応用セラミックス研究所 研究員・博士 (工学)
Assoc. Prof., Dept. of Built Environment, Interdisciplinary Graduate School, Tokyo Institute of Technology, Dr. Eng.

Research Engineer, Materials and Structures Laboratory, Tokyo Institute of Technology, Dr. Eng. 


\section{2. 调材に対する基礶方程式}

まず文献 12)に示すトラス要素における弾塑性座屈評価手法に基 つき個材に対する基䃛方程式を示す。個材 $\alpha$ に対して Fig.2 に示すよ うな弾性棒と弾塑性回転バネから成る単純化した弾塑性座届評価モ デルを考えると、Helmholtzの自由エネルキー $\psi_{\alpha}{ }^{7}$ は次式で表される。

$$
\psi_{\alpha}\left(u_{\alpha}, \theta_{\alpha}, u_{\alpha}^{p}, \theta_{\alpha}^{p}\right)=\left\{\frac{1}{2^{n}} k_{\alpha}\left(\frac{u_{\alpha}}{2}-\frac{u_{\alpha}^{p}}{2}-\frac{l_{\alpha}}{4} \theta_{\alpha}{ }^{2}\right)^{2}+\frac{1}{2}{ }^{m} k_{\alpha}\left(\theta_{\alpha}-\theta_{\alpha}^{p}\right)^{2}\right\} \times 2
$$

ここに、 $n_{a}$ は個材軸力、 $u_{\alpha}, u_{\alpha}^{p}, \theta_{\alpha}, \theta_{\alpha}{ }^{p}$ は個材全伸縮量、回転バネの塑 性化による塑性伸緶量、回転バネの全回転量および塑性成分をそれ ぞれ表しており、 ${ }_{n} k_{\alpha},{ }_{m} k_{\alpha}, l_{a}$ は弾性棒の軸剛性、回転バネの弾性回転 㣚性および個材長である。本論文において個材は降伏するまで座屈 しない完全弾塑性体を対象とし、 $\theta_{\alpha} \geq 0$ とする。

熱力学における第 2 法則を表す Clausius-Duhem の不等式》は力学 問題に限定すれば次式で表される。

$$
-\dot{\psi}_{\alpha}+n_{\alpha} \dot{u}_{\alpha} \geq 0
$$

ここに、（）はそれぞれの速度を表すものとする。上式が任意の $u_{\infty}, \theta_{\alpha} に$ 対して成り立つことから次の関係が得られる。

$$
\begin{aligned}
& n_{\alpha}=\frac{1}{2^{n}} k_{\alpha}\left(u_{\alpha}-u_{\alpha}^{p}-\frac{l_{\alpha}}{2} \theta_{\alpha}^{2}\right) \\
& n_{\alpha} l_{\alpha} \theta_{\alpha}=2_{m} k_{\alpha}\left(\theta_{\alpha}-\theta_{\alpha}^{p}\right) \Rightarrow 2 m_{\alpha} \\
& \Gamma_{\alpha}=n_{\alpha} \dot{u}_{\alpha}^{p}+n_{\alpha} l_{\alpha} \theta_{\alpha} \dot{\theta}_{\alpha}^{p} \geq 0
\end{aligned}
$$

ここに、 $m_{\alpha}$ は Fig.2(b)に示す回転バネに作用する曲げである。上記 の第 1 式は $n_{\alpha}-u_{\alpha}$ 間の弾性構成則、第 2 式は Fig.2(b)中の点 B での モーメントのつりあい式を表しておる。第 3 式の $\Gamma_{\alpha}$ は塑性散逸項 ${ }^{8)}$ と呼ばれ、この表現は $n_{\alpha}, n_{\alpha} l_{\alpha} \theta_{\alpha}$ が $u_{\alpha}^{p}, \theta_{\alpha}{ }^{p}$ に対する熱力学的力に相 当することを示している。

式(4)で表される回転バネにおける降伏条件式は、式(3)により式 (5)のように書き換えられる。

$$
\begin{aligned}
& \Phi_{\alpha}\left(n_{\alpha}, m_{\alpha}\right)=\left(n_{\alpha} / n_{y}\right)^{2}+\left|m_{\alpha}\right| / m_{p}-1 \leq 0 \\
& \Phi_{\alpha}\left(n_{\alpha}, \theta_{\alpha}\right)=\frac{\left|n_{\alpha}\right|}{n_{y}}-\bar{\tau}_{\alpha}\left(\theta_{\alpha}\right) \leq 0 \\
& \bar{\tau}_{\alpha}\left(\theta_{\alpha}\right)=\bar{\sigma}_{\alpha}\left(\theta_{\alpha}\right)-\frac{n_{y} l_{\alpha} \theta_{\alpha}}{4 m_{p}}, \quad \bar{\sigma}_{\alpha}\left(\theta_{\alpha}\right)=\sqrt{1+\left(\frac{n_{y} l_{\alpha} \theta_{\alpha}}{4 m_{p}}\right)^{2}}
\end{aligned}
$$

ここに $n_{y}, m_{p}$ はそれぞれ $n_{\alpha}, m_{\alpha}$ に対する全塑性耐力である。式(5)から 有効降伏応力 $\bar{\tau}_{a} に よ り$ 座屈を硬化・軟化特性として評価できること が解る。ここで、降伏条件式に対して最大塑性散逸の原理 ${ }^{8)}$ を導入 し、次の Lagrangian を考える。

$$
L_{\alpha}=-\Gamma_{\alpha}+\dot{\lambda}_{\alpha}^{p} \Phi_{\alpha}
$$

ここに、 $\lambda_{\alpha}^{p}$ は Lagrange 乗数であり、塑性進展パラメータと呼ばれ、 式(4)が active な場合次の条件を満たす。

$$
\Phi_{\alpha}=0, \quad \dot{\Phi}_{\alpha}=0 \text { and } \dot{\lambda}_{a}^{p} \geq 0
$$

次に $n_{\alpha}, m_{\alpha}$ に関して $L_{\alpha}$ の導関数をとることにより個材に対する塑性

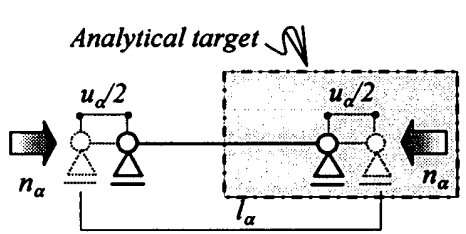

(a) Member model

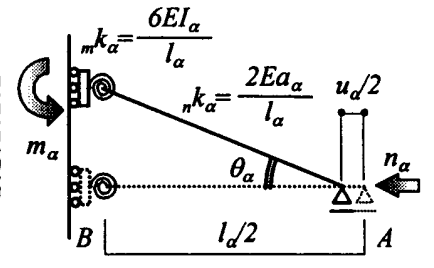

(b) Elastoplastic buckling model
Fig.2 Single chord member

流れ則が求まる。

$$
\dot{u}_{\alpha}^{p}=\frac{n_{\alpha}}{n_{y}{ }^{2}} \frac{1}{\bar{\sigma}_{\alpha}} \dot{\lambda}_{\alpha}^{p}, \quad \dot{\theta}_{\alpha}^{p}=\frac{1}{4 m_{p}} \frac{n_{\alpha}}{\left|n_{\alpha}\right|} \frac{1}{\bar{\sigma}_{\alpha}} \dot{\lambda}_{\alpha}^{p}
$$

ここで、細長比が比較的小さい場合を対象とした近似解法として $\theta_{\alpha} \cong \theta_{\alpha}^{p}$ が成り立つと仮定すると、式(5)の降伏関数は次式のように 書き換えられる。

$$
\begin{aligned}
& \Phi_{\alpha}\left(n_{\alpha}, \lambda_{\alpha}^{p}\right)=\frac{\left|n_{\alpha}\right|}{n_{y}}-\bar{\tau}_{\alpha}\left(\lambda_{\alpha}^{p}\right) \leq 0 \\
& \bar{\tau}_{\alpha}\left(\lambda_{\alpha}^{p}\right)=\bar{\sigma}_{\alpha}\left(\lambda_{\alpha}^{p}\right)-\frac{n_{y} l_{\alpha} \theta_{\alpha}^{p}\left(\lambda_{\alpha}^{p}\right)}{4 m_{p}}, \quad \bar{\sigma}_{\alpha}\left(\lambda_{\alpha}^{p}\right)=\sqrt{1+\left(\frac{n_{y} l_{\alpha} \theta_{\alpha}^{p}\left(\lambda_{\alpha}^{p}\right)}{4 m_{p}}\right)^{2}}
\end{aligned}
$$

また、個材伸縮量に対して塑性成分 $u_{\alpha}^{p}$ と座屈による成分 $u_{\alpha}^{b}$ を用い て加法的に表される有効塑性伸縮量 $u_{\alpha}^{p b}$ を考えると、 $u_{\alpha}^{p b}$ に対して塑 性流れ則が式(11)のように求められる。

$$
\begin{aligned}
& u_{\alpha}^{p b}=u_{\alpha}^{p}+u_{\alpha}^{b} 、 \quad u_{\alpha}^{b}=\frac{l_{\alpha}}{2} \theta_{\alpha}^{p^{2}} \\
& \dot{u}_{\alpha}^{p b}=\dot{u}_{\alpha}^{p}+l_{\alpha} \theta_{\alpha}^{p} \dot{\theta}_{\alpha}^{p}=\frac{1}{n_{y}} \frac{n_{\alpha}}{\left|n_{\alpha}\right|} \dot{\lambda}_{\alpha}^{p}
\end{aligned}
$$

なお、式(7)に示す負荷条件（ $\dot{\lambda}_{a}^{p} \geq 0 ）$ より、個材に対して次の条件 式が得られる。

$$
\frac{1}{n_{y}{ }^{2}} \frac{{ }_{n} k_{\alpha}}{2}-\frac{n_{\alpha} l_{\alpha}}{16 m_{p}{ }^{2} \bar{\sigma}_{\alpha}^{2}}>0
$$

\section{3. トラス果に対する伊析手法}

\section{1 トラス染に対する基碳方程式}

本論文では個材の細長比が比較的小さい場合を対象に式(13)が成 り立つと仮定した近似解法について示す。

$$
\theta_{\alpha} \cong \theta_{\alpha}^{p}
$$

まず、個材が塑性化または座屈した場合のトラス梁に対する材端相 対変位ベクトル $\tilde{\boldsymbol{u}}$ の塑性成分 $\tilde{\boldsymbol{u}}^{p}$ および座屈成分 $\tilde{\boldsymbol{u}}^{b}$ の進展につい て述べる。トラス梁に対する Helmholtz の自由エネルキールは個材 に対するものの総和をとることにより次式のように表される。

$$
\Psi=\sum_{\alpha=1}^{a l l} \psi_{\alpha}\left(u_{\alpha}, u_{\alpha}^{p}, \theta_{\alpha}^{p}\right)
$$

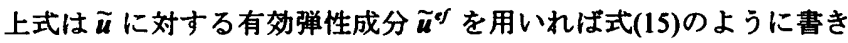
換えられる。

$$
\Psi=\frac{1}{2} \tilde{u}^{e f^{T}} \boldsymbol{k}^{e} \tilde{u}^{e f}
$$

ここに、( $)^{T}$ は転置を表し、 $\boldsymbol{k}^{\boldsymbol{e}}$ は文献 11)に示すものと同じトラス梁

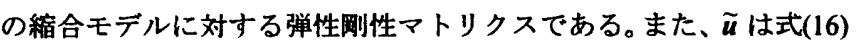
に示すように $\tilde{u}^{e f}, \tilde{\boldsymbol{u}}^{p}, \tilde{\boldsymbol{u}}^{b} に よ り$ 加法的に表現されるとする。 


$$
\tilde{\boldsymbol{u}}=\tilde{\boldsymbol{u}}^{e f}+\tilde{\boldsymbol{u}}^{p}+\tilde{\boldsymbol{u}}^{b}, \quad \tilde{\boldsymbol{u}}^{T}=\left\langle\begin{array}{lll}
\tilde{\boldsymbol{\delta}} & \tilde{\boldsymbol{\theta}}_{1} & \tilde{\boldsymbol{\theta}}_{j}
\end{array}\right\rangle
$$

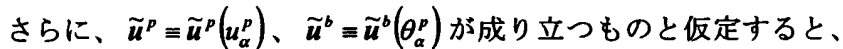
$\tilde{\boldsymbol{u}}^{p}, \tilde{\boldsymbol{u}}^{b}$ は次式のように表現できる。

$$
\begin{aligned}
& \dot{\tilde{u}}^{p}\left(u_{\alpha}^{p}\right)=\sum_{\alpha=1}^{a l l} \frac{\partial \widetilde{u}^{p}}{\partial u_{\alpha}^{p}} \dot{u}_{\alpha}^{p} \equiv \sum_{\alpha=1}^{a l l} h_{\alpha}^{p} \dot{u}_{\alpha}^{p} \\
& \dot{\tilde{u}}^{b}\left(\theta_{\alpha}^{p}\right)=\sum_{\alpha=1}^{a l l} \frac{\partial \widetilde{u}^{b}}{\partial \theta_{\alpha}^{p}} \dot{\theta}_{\alpha}^{p} \equiv \sum_{\alpha=1}^{a l l} h_{\alpha}^{b} \dot{\theta}_{\alpha}^{p}
\end{aligned}
$$

トラス梁に対してClausius-Duhemの不等式は次式のように表される。

$$
-\dot{\Psi}+\boldsymbol{f}^{T} \dot{\tilde{u}}=\left\{\boldsymbol{f}-\boldsymbol{k}^{\boldsymbol{c}} \tilde{\boldsymbol{u}}^{\sigma f}\right\} \dot{\tilde{u}}+\sum_{\alpha=1}^{a l l}\left[\boldsymbol{f}^{T} \boldsymbol{h}_{\alpha}^{p} \dot{u}_{\alpha}^{p}+\boldsymbol{f}^{T} \boldsymbol{h}_{\alpha}^{b} \dot{\theta}_{\alpha}^{p}\right] \geq 0
$$

ここに、fは材端カベクトルであり、 $f^{T}=\left\langle\begin{array}{lll}N & M_{i} & M_{j}\end{array}\right\rangle$ である。 上式が任意の $\tilde{\boldsymbol{u}}$ に対して成り立つことから次の関保が得られる。

$$
\begin{aligned}
& \boldsymbol{f}=\boldsymbol{k}^{e} \widetilde{\boldsymbol{u}}^{e f} \\
& \Gamma=\sum_{\alpha=1}^{a l l}\left[\boldsymbol{f}^{T} \boldsymbol{h}_{\alpha}^{p} \dot{u}_{\alpha}^{p}+\boldsymbol{f}^{T} \boldsymbol{h}_{\alpha}^{b} \dot{\theta}_{\alpha}^{p}\right] \geq 0
\end{aligned}
$$

第 1 式はトラス梁の縮合モデルに対する弾性構成則、第 2 式 $\Gamma$ は塑 性散逸項であり、式(3-c)と比較することにより得られる解の一つと して、 $\boldsymbol{h}_{\alpha}^{p}, \boldsymbol{h}_{\alpha}^{b}$ は $\boldsymbol{h}_{\alpha}$ を用いて次のように表される。

$$
\begin{array}{ll}
\boldsymbol{h}_{\alpha}^{p}=\boldsymbol{h}_{\alpha} 、 & \boldsymbol{h}_{\alpha}^{b}=\boldsymbol{h}_{\alpha} l_{\alpha} \theta_{\alpha}^{p} \\
\boldsymbol{n}_{\alpha}=\boldsymbol{f}^{T} \boldsymbol{h}_{\alpha} 、 & \boldsymbol{h}_{\alpha}=\left(\frac{1}{2} \pm \frac{1-\xi_{\alpha}}{H} \mp \frac{\xi_{\alpha}}{H}\right)^{T}
\end{array}
$$

ここに、 $\xi$ は Fig.3 に示す部材座標系であり、 $\xi_{\alpha}$ は個材 $\alpha$ の軸力重 心位㯰(Fig.3 中の四)での $\xi$ 値である。なお、複号に関して上符号は 上弦材を示し、下符号は下弦材を示す。

一方、式(9)で表される個材の降伏条件式をトラス梁に対する降伏 条件式として捉えると式(22)のように書き換えることができ、式 (20)(21)よりトラス梁の塑性および座届変位速度は降伏関数の勾配 に垂直であることが解る。このことはトラス梁に対して Associate flow 則が成り立つことを表しており、式(17)は搪張した Koiter の考 え方りと同じ表現となっている。

$$
\Phi_{\alpha}\left(f, \lambda_{\alpha}^{p}\right)=\frac{\left|f^{T} h_{a}\right|}{n_{y}}-\bar{\tau}_{a}\left(\lambda_{\alpha}^{p}\right) \leq 0
$$

または、

$$
\begin{aligned}
& \Phi_{\alpha}\left(f, \lambda_{\alpha}^{p}\right)=\left|v \pm\left(1-\xi_{\alpha}\right) \mu_{i} \mp \xi_{\alpha} \mu_{j}\right|-\bar{\tau}_{\alpha}\left(\lambda_{\alpha}^{p}\right) \leq 0 \\
& \bar{\tau}_{\alpha}\left(\lambda_{\alpha}^{p}\right)=\bar{\sigma}_{\alpha}\left(\lambda_{\alpha}^{p}\right)-\frac{n_{y} l_{\alpha} \theta_{\alpha}^{p}}{4 m_{p}} 、 \bar{\sigma}_{\alpha}\left(\lambda_{\alpha}^{p}\right)=\sqrt{1+\left(\frac{n_{y} l_{\alpha} \theta_{\alpha}^{p}}{4 m_{p}}\right)^{2}}
\end{aligned}
$$

ここに、 $v=N / N_{y} 、 \mu_{i}=M_{i} / M_{p} 、 \mu_{j}=M_{j} / M_{p}$ であり、 $N_{y}=2 n_{y} 、$ $M_{p}=n_{y} H$ である。また、座屈による硬化・軟化特性は式(23)(8)よ り次のように求められる。

$$
\dot{\bar{\tau}}_{\alpha}=\frac{\partial \bar{\tau}_{\alpha}}{\partial \theta_{\alpha}^{p}} \frac{\partial \theta_{\alpha}^{p}}{\partial \lambda_{\alpha}^{p}} \dot{\lambda}_{\alpha}^{p}=-\frac{n_{\alpha} l_{\alpha}}{16 m_{p}^{2}} \frac{1}{\bar{\sigma}_{\alpha}\left(\theta_{\alpha}^{p}\right)^{2}} \dot{\lambda}_{\alpha}^{p}
$$

式(22)から明らかなように式(13)の仮定により弾塑性座届問題を 硬化・㳄化特性を有する弾塑性問題として扱うことが可能となる。 また、この座屈による硬化・軟化特性は、 $\bar{\tau}_{\alpha}$ が対象個材 $\alpha$ の塑性進 展パラメータのみの関数であることから、 $\left(\mu_{i}, \mu_{j}, v\right)$ 空間において所謂

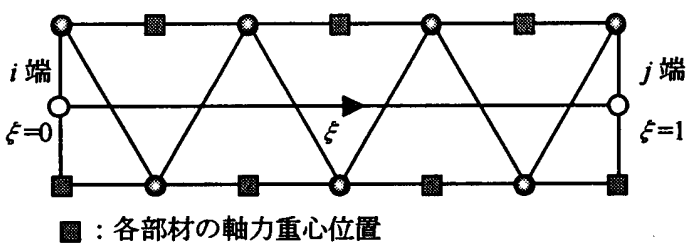

Fig.3 Local coordinate system

Multi-surface として表現された降伏面のうち、圧縮と引張で対とな る個材 $\alpha$ に対応する降伏面のみの移動として表現される。

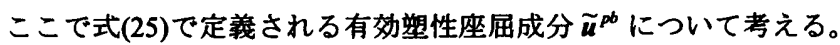
$\tilde{\boldsymbol{u}}^{p b}=\tilde{\boldsymbol{u}}^{p}+\tilde{\boldsymbol{u}}^{b}$

式(25)を速度表記し、式(17)を代入したものと式(11)を比較すること により $\widetilde{\boldsymbol{u}}^{p b}$ に対する塑性流れ則が求められる。

$$
\dot{\tilde{u}}^{p b}=\sum_{\alpha=1}^{a l l} \frac{1}{n_{y}} \frac{f^{T} h_{\alpha}}{\left|f^{T} h_{\alpha}\right|} h_{\alpha} \dot{\lambda}_{\alpha}^{p} \Leftrightarrow \sum_{\alpha \in a c t i v e} \frac{1}{n_{y}} \frac{f^{T} h_{\alpha}}{\left|f^{T} h_{\alpha}\right|} h_{\alpha} \dot{\lambda}_{\alpha}^{p}
$$

$\because \dot{\lambda}_{\beta}^{p}=0$ for $\Phi_{\beta}<0$

また、 $\tilde{\boldsymbol{u}}^{p b}$ を用いて塑性散逸項を表すと、

$$
\Gamma=f^{T} \dot{\tilde{u}}^{p b} \geq 0
$$

となることからトラス梁において $\tilde{u}^{p b}$ に対する熱力学的力が $f$ に相 当することが解る。

\section{2 弾塑性接線㖿性}

active である降伏関数 $\Phi_{\alpha}$ に対して $\dot{\Phi}_{\alpha}=0$ が成り立つことから、

$$
\begin{aligned}
\dot{\Phi}_{\alpha} & =\left\{\frac{\partial \Phi_{\alpha}}{\partial f}\right\}^{T} \dot{\boldsymbol{f}}-\frac{\partial \bar{t}_{\alpha}}{\partial \lambda_{\alpha}^{p}} \dot{\lambda}_{\alpha}^{p} \\
& =\frac{1}{n_{y}} \frac{n_{\alpha}}{\left|n_{\alpha}\right|} \boldsymbol{h}_{\alpha}{ }^{T} \boldsymbol{k}^{e}\left\{\dot{\tilde{u}}-\dot{\tilde{u}}^{p b}\right\}-\frac{\partial \bar{\tau}_{\alpha}}{\partial \lambda_{\alpha}^{p}} \dot{\lambda}_{\alpha}^{p} \\
& =\frac{1}{n_{y}} \frac{n_{\alpha}}{\left|n_{\alpha}\right|} \boldsymbol{h}_{\alpha}{ }^{T} \boldsymbol{k}^{e}\left\{\dot{\tilde{\boldsymbol{u}}}-\sum_{\beta \in \alpha c t i v e} \frac{1}{n_{y}} \frac{n_{\beta}}{\left|n_{\beta}\right|} \boldsymbol{h}_{\beta} \dot{\lambda}_{\beta}^{p}\right\}-\frac{\partial \bar{\tau}_{\alpha}}{\partial \lambda_{\alpha}^{p}} \dot{\lambda}_{\alpha}^{p}=0
\end{aligned}
$$

したがって、 $\lambda_{\alpha}^{p} に$ 対する連立方程式が欣式のように求められる。

$$
\sum_{\beta \in a c t i v e} G_{\alpha \beta} \dot{\lambda}_{\beta}^{p}=\frac{1}{n_{y}} \frac{n_{\alpha}}{\left|n_{\alpha}\right|} h_{\alpha}{ }^{T} k^{e} \dot{\tilde{u}} \quad \text { for } \quad \alpha \in \text { active }
$$
ここに、

$$
G_{\alpha \beta}=\frac{1}{n_{y}{ }^{2}} \frac{n_{\alpha}}{\left|n_{\alpha}\right|} \frac{n_{\beta}}{\left|n_{\beta}\right|} h_{\alpha}{ }^{T} k^{c} h_{\beta}-\frac{n_{\alpha} l_{\alpha}}{16 m_{p}{ }^{2} \bar{\sigma}_{\alpha}{ }^{2}} \delta_{\alpha \beta}
$$

$\delta_{\alpha \beta}:$ クロネッカーのデルタ

ここで、 $G_{\alpha \beta}$ の逆マトリクスの成分 $G^{\beta \alpha}$ を用いると、 $\lambda_{\alpha}^{p}$ は次式のよ うに表現され、

$$
\dot{\lambda}_{\alpha}^{p}=\frac{1}{n_{y}} \sum_{\beta \in \text { eacive }} G^{\alpha \beta} \frac{n_{\beta}}{\left|n_{\beta}\right|} h_{\beta}^{T} k^{e} \dot{\tilde{u}}
$$

接線剛性マトリクス $\boldsymbol{k}^{e p b}$ は次式のように表現される。

$$
\begin{aligned}
& \dot{f}=\left[k^{e}-\frac{1}{n_{y}{ }^{2}} \sum_{\alpha \in \alpha c t i v e} \sum_{\beta \in \text { active }} \frac{n_{\alpha}}{\left|n_{\alpha}\right|} \frac{n_{\beta}}{\left|n_{\beta}\right|} G^{\alpha \beta}\left(k^{e} h_{\alpha}\right) \otimes\left(k^{e} h_{\beta}\right)\right] \dot{\tilde{u}} \equiv k^{e p b} \dot{\tilde{u}} \\
& \otimes: \text { テンソル積 }
\end{aligned}
$$




\section{4. 数俌解析}

\section{1 材端力の算定手順}

次に具体的に增分変位が求められた段階での材端力ベクトルの算 定手順について述べ。この手順は基本的には文献 11)に示す個材 が塑性化する場合と同じであり、近似解法を用いることにより弾塑 性座屈問題を硬化·軟化特性を有する弾塑性問題として扱っている。 今、状態たtにおける塑性変位ベクトル、塑性進展パラメータ、塑性 回転変位（' $\left.\tilde{\boldsymbol{u}}^{p},{ }^{\prime} \lambda_{\alpha}^{p},{ }^{\prime} \theta_{a}^{p}\right)$ および状態 $\mathrm{t}=t+\Delta t$ における材端変位べク トル $\left({ }^{l+\Delta} \tilde{u}\right)$ が既知であるものとする。

\section{弾性試行段階}

この計算段階では、塑性変位増分および座届変位增分は生じない ものとして試行值の計算が行われる。すなわち、

$$
\begin{aligned}
& \Delta \lambda_{\alpha}^{p}=0, \quad \quad{ }^{\text {trial }} \lambda_{\alpha}^{p}=t \lambda_{\alpha}^{p}, \quad{ }^{\text {trial }} \theta_{\alpha}^{p}={ }^{t} \theta_{\alpha}^{p} \\
& \Delta \tilde{u}^{p b}=0, \quad \quad{ }_{\text {rrial }} \tilde{u}^{p b}={ }^{t} \tilde{u}^{p b}
\end{aligned}
$$

これを式(19-a)(23)に代入することにより、試行応力が求められる。 なお、 $\Delta()$ は增分値を表す。

$$
\begin{aligned}
& { }^{\text {trial }} f=\boldsymbol{k}^{e}\left({ }^{++\Delta} \tilde{\boldsymbol{u}}-{ }^{\text {trial }} \tilde{\boldsymbol{u}}^{p b}\right) \\
& { }_{\text {tral }} \bar{\tau}_{\alpha}=\sqrt{1+\frac{n_{y}{ }^{2} l_{\alpha}{ }^{2 \text { trial }} \theta_{\alpha}^{p^{2}}}{16 m_{p}{ }^{2}}}-\frac{n_{y} l_{\alpha}{ }^{\text {trial }} \theta_{\alpha}^{p}}{4 m_{p}}
\end{aligned}
$$

この結果を用いてすべての個材に対して試行降伏関数値を計算する。

$$
{ }^{\text {rial }} \Phi_{\alpha}\left({ }^{\text {rial }} f,{ }^{\text {rial }} \theta_{\alpha}^{p}\right)=\frac{||^{\text {trial }} f^{T} h_{\alpha} \mid}{n_{y}}{ }^{\text {trial }} \bar{\tau}_{\alpha}
$$

式(35) にて計算された ${ }^{\text {trial }} \Phi_{\alpha}$ が正であれば個材 $\alpha$ は塑性進展過程に あると判断され、負であれは、弾性状態（除荷状態を含む）にある と判断される。前者の場合には後述する塑性修正段階を実行するこ とにより、真の解を求める。

\section{塑性修正段階}

弾性試行計算により、個材 $\alpha$ は塑性進展過程にあると判断された ので、塑性変位を准展させ応力を解放し、試行值から真の解を計算 する。そこで、各試行值を用いて状热 $t=t+\Delta t$ における真の降伏関数 值を表現する。まず、状態 $\mathrm{t}=t+\Delta t$ における材端力べクトルと有勃降 伏応力は有効塑性座届変位および個材の塑性回転量の增分值を用い て次のように表現される。

$$
\begin{aligned}
& { }^{t+\Delta t} f={ }^{\text {trial }} f-k^{e} \Delta \tilde{u}^{p b}
\end{aligned}
$$

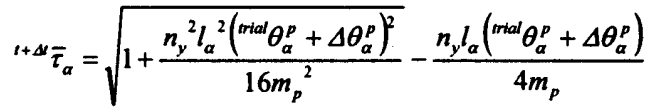

式(36)を降伏関数に代入することにより $\Delta \lambda_{\alpha}^{p}(\alpha \in$ active $)$ に関する連 立方程式が得られる。これは非線形方程式であるので、Newton 法に より解く。

$$
\begin{aligned}
& \underset{(k+1)}{l+\Delta t} \Phi_{\alpha} \cong_{(k)}^{l+\Delta \beta} \Phi_{\alpha}+\sum_{\beta \text { Gactive }} \frac{\partial^{i+\Delta} \Phi_{\alpha}}{\partial \Delta \lambda_{\beta}^{p}} \delta \Delta \lambda_{\beta}^{p}
\end{aligned}
$$

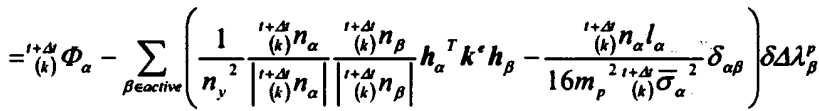

$$
\begin{aligned}
& ={ }^{++\Delta)}(k) \Phi_{\alpha}-\sum_{\beta \in a c t \text { the }}{ }_{(k)}^{++\Delta} G_{\alpha \beta} \delta \Delta \lambda_{\beta}^{p}=0 \\
& \text { for } \alpha \in \text { active }
\end{aligned}
$$

ここに、下指標 $(k)$ は iteration 回数を表す。これより、 $\delta \Delta \lambda_{\alpha}^{p}$ が次のよ うに求められる。

$$
\delta \Delta \lambda_{\alpha}^{p}=\sum_{\beta \in \text { eactive }}^{1+\Delta(k)} G_{(k)}^{\alpha \beta t+\Delta \beta} \Phi_{\beta}
$$

この $\delta \Delta \lambda_{\alpha}^{p}$ を用いて各值の更新を行い、|$\left|{ }_{(k+1)}^{i+\Delta \mu} \Phi_{\alpha}\right| \leq$ Tolerance または $\left|\delta \Delta \lambda_{\alpha}^{p}\right| \leq$ Tolerance となるまで iteration を繰り返す。

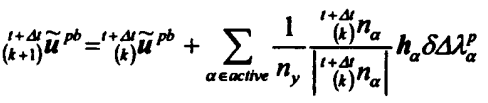

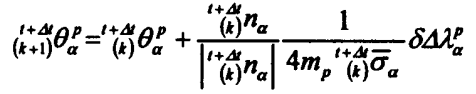

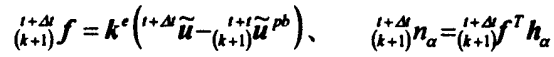

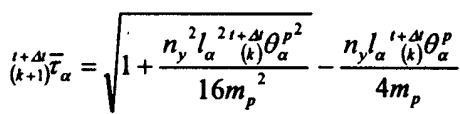

なお、複数の降伏条件式が active である状態で、iteration 過程にお いてある個材の応力を緩和することにより他の降伏条件式 $\left(\Phi_{a}\right)$ が active ではなくなる場合 $\left(\begin{array}{c}1+\Delta t \\ (k+1)\end{array} \Delta \lambda_{\alpha}^{p}<0\right)$ が考えられる。この場合には、 $\left(\Phi_{a}\right)$ を active 条件集合から除き、初期条件を再計算することにより 対処している。また、座屈を考慮する場合には $\delta \Delta \lambda_{\alpha}^{p}$ を求める際に解 が不定となる場合が考えられるが、この場合の解法として文献 13) に示す固有値を用いた解法を採用している。ただし、本論文で示す 解析例では該当する場面はなかった。

\section{2 解析モデル}

解析対象は、文献 11)に示すものと同様のピン接合された細長比 40 (下弦材端部は 20）の個材から成るワーレン型トラス梁である。 モデル諸量は、 $L=34.641[\mathrm{~cm}] 、 H=10[\mathrm{~cm}] 、 \theta=60\left[^{\circ}\right] 、 a_{c}=a_{d}=1\left[\mathrm{~cm}^{2}\right] 、$ $E=206[\mathrm{GPa}]$ とし、弦材は降伏志力度 $\sigma_{\mathrm{y}}=235[\mathrm{MPa}]$ の完全弾塑性体で あるとした。また、斜材については弾性体かつ座屈しないものとし、 両端部の束材は剛体とした。外力は単調載荷および繰返し載荷を設 定し、それぞれ以下の載荷パターンを満足するように変位制御によ り作用させるものとする。

\section{単調載荷 ：各降伏曲面の変化の考察等を容易にするため} の載荷パターン $\left(M_{j}=0, \tilde{\delta}=2 H \tilde{\theta}_{i}\right)$

綝返し載荷：個材座屈に対応する圧縮側の降伏曲面と対と なる引張側降伏曲面の変化の考察等を容易に するための載荷パターン $\left(M_{j}=0, \tilde{\delta}=H \tilde{\theta}_{i}\right)$

本解析手法ではトラス梁全体を 1 要素として解析を行っている。 なお、比較検討のために弦材を 2 節点アイソパラメトリック梁要素、 斜材・束材を 2 節点トラス要素によりモデル化した解析も行ってい る(以下離散化モデル)。離散化モデルにおける弦材については 1 個材を 10 要素に分割している。初期不整は固有值解析により求めら れたそれぞれの個材に対する 1 次固有モードに対し、細長比 40 の個 材については最大振幅が個材長の $1 / 10^{4}$ 、細長比 20 の個材について は $1 / 10^{3}$ として与えている。 


\section{3 解析結果と考察}

以下に解析結果を示す。いずれの図においてもプロットが本解析 手法による結果であり、実線が離散化モデルによる結果を表す。 Fig. 5 に $\mu_{i}-\nu$ 平面における応力の推移を、Fig.6,7 に荷重変位関係を示 す。荷重変位関俰において無次元化に用いた $\tilde{\delta}_{y}, \tilde{\theta}_{p}$ はそれぞれ降伏 軸耐力 $N_{y}$ に対する弾性軸変位值および他端の曲げモーメントを零 とした場合の全塑性曲げ耐力 $M_{p}$ に対する弾性回転変位値を表す。 $<$ 単調載荷 $>$

まず、単調載荷の場合の解析結果について考察する。Fig.5におい て応力は初期許容応力空間内を推移し、個材(1)に対する圧縮側の降 伏面 $\left(\Phi_{1}^{-}=0\right)$ とぶつかる点 $(\nabla)$ において個材(1)が座屈する。その後、 個材(1)座屈の進展に伴い降伏面 $\left(\Phi_{1}^{-}=0\right)$ は矢印のように初期許容 忘力空間内部一移動し、応力推移線が個材(4)に対する圧縮側の降伏 面 $\left(\Phi_{4}^{-}=0\right)$ とぶつかることにより個材(4)も座届する。これ以降、個 材(1)(4)の座屈の進展に伴い、それぞれの降伏面は初期許容忘力空間 内部に移動していく。また、この忘力推移線と各降伏面がぶつかる 点は、Fig.8 に示す各変位段階における個材(1)(4)の軸力の推移から解 る座屈点に対応し、Fig.6,7においては荷重変位関保の折れ曲り点に 対応する。ここで注目すべきは軸力-軸変位関保だけを見ると個材(1) の座屈後、軸耐力は上昇していることである。これは Fig.8 から解 るように個材(1)の座屈後個材(4)の軸力が上昇した為であるが、この ことから個材座届の影響を単に荷重変位関係のみで評価するのでは なく、 $\left(\mu_{i}, \mu, v\right)$ 空間において評価すべきであると言える。

\section{<繰返し載荷 $>$}

次に繰返し載荷の場合について考察する。単調載荷の場合と同様 に、Fig.5において個材(1)の座届に伴い降伏面 $\left(\Phi_{1}^{-}=0\right)$ が矢印のよう に移動する。この時個材(1)に対応する引張側の降伏面 $\left(\Phi_{1}^{+}=0\right)$ も初 期許容応力空間内部を矢印のように移動しており、逆方向載荷によ り応力推移線がこの移動してきた降伏面 $\left(\Phi_{1}^{+}=0\right)$ とぶつかる点 $(\nabla)$ は荷重変位関係における折れ曲り点に対応する。その後、個材(1)に 引張力が作用することにより座屈が回復し、降伏面 $\left(\Phi_{1}^{+}=0\right)$ は初期 状態へと近ついていく。この過程における挙動は Fig.6,7 からも解る ように非弾性ではあるが耐力上昇を伴い、座屈における硬化現象と して捉えることができる。更に、この時降伏面 $\left(\Phi_{1}^{-}=0\right)$ も同様に回 復しており、再載荷過程において忘力推移線がこの回復した降伏面 $\left(\Phi_{1}^{-}=0\right)$ とぶつかる点において個材(1)は再座屈する。なお、文献 12) では個材の座届举動に関して、降伏応力度に対し細長比が比較的大 きい場合には緣り返し載荷の際の除荷域において五十嵐らによる解 と著しい差が見られることを示しているが、本論文で用いた解析モ デルは近似解法を適用し得る䉪囲の降伏応力度・細長比関俰である と言える。

以上のようにいずれの図においても本縮合モデルと離散化モデル による解析結果は良く一致していることから、単調載荷および綝返 し载荷に関わらず本解析手法が妥当であると言える。また、本手法 は計算負荷の低減のみならず、有効降伏応力の評価により個材の座 屈進展程度を容易に把握できるという点においても有効である。更 に本手法では初期不整を必要としないことから、絽返し載荷等にお いて個材に引張力が作用し座屈が完全に回復した場合、離散化モデ ルでは再載荷時に座屈を表現できなくなるのに対し、本手法では座 届を容易に評価し得るという利点もある。

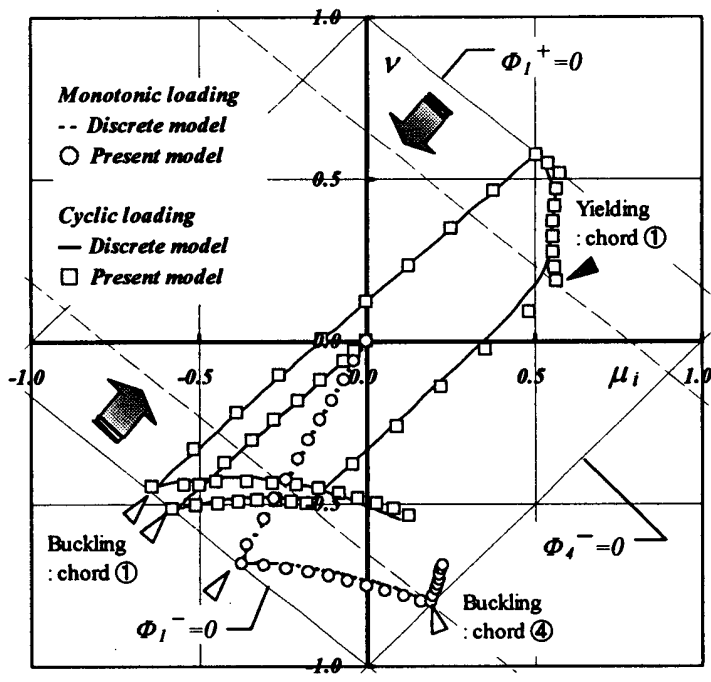

Fig.5 $v-\mu_{i}$ correlation

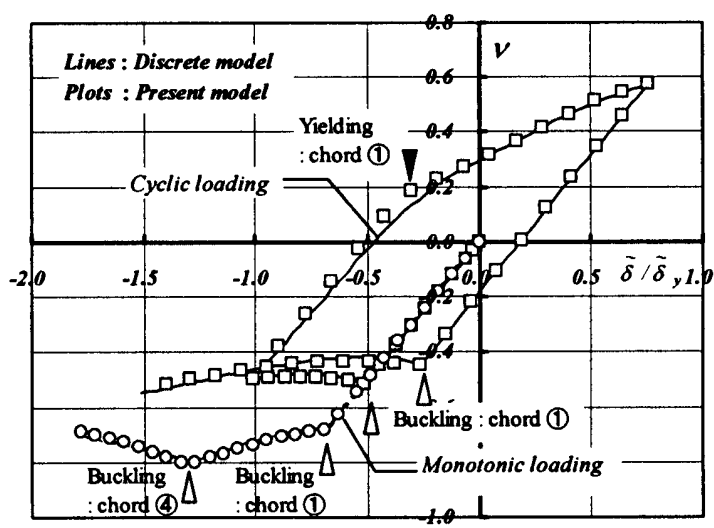

Fig.6 Load-displacement curve

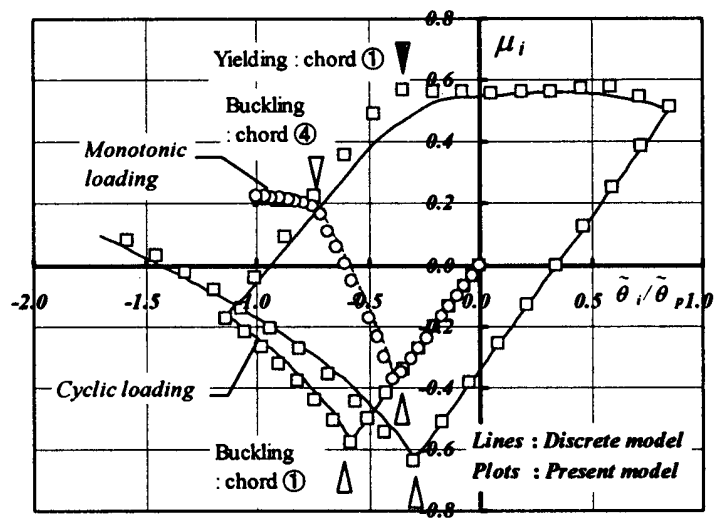

Fig.7 Load-displacement curve

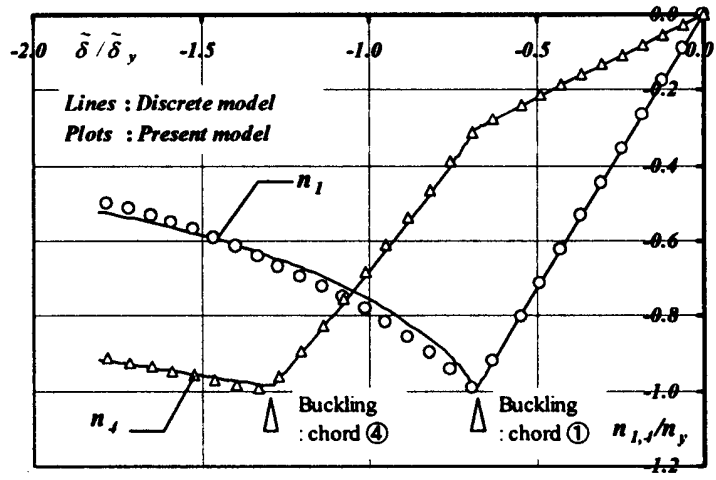

Fig.8 Chord member's axial force-displacement curve (monotonic) 


\section{5. まとめ}

本論文では個材の座屈を考㦄したワーレン型トラス梁に対して維 合モデルを用いた熱力学に基つく解析手法の適用について論じた。 結果をまとめると、

i）個材の座屈を考虑する場合にも、個材に対する降伏条件式を材 端力に対する降伏条件式と固き換えることにより、トラス梁と しての降伏曲面は $\left(M_{i}, M_{i}, N\right)$ 空間における Multi-surface として表 現される。

ii）個材の塑性化および座屈によるトラス梁の塑性・座届变位成分 に対する流れ則について、Associate flow則および抬張した Koiter の考え方が成り立つ。

iii）トラス梁における個材座届の影響は硬化・軟化特性として評価 でき、個材の細長比が比較的小さい場合を対象に $\theta_{\alpha} \cong \theta_{\alpha}^{p}$ が成り 立つと仮定することにより、トラス梁に対する弾塑性座屈問題 を硬化・軟化特性を有する弾塑性問題として扱うことが可能と なる。

iv) 個材の座屈によるトラス梁としての硬化・軟化特性は Multi-surface のうち座届した個材に対応し圧縮と引張で対とな る降伏面のみの移動として表現される。

v) 本手法により定式化された縮合モデルと離散化モデルによる解 析結果とを比較することにより、本手法の妥当性および有効性 を示した。

本論文では個材の細長比が小さい場合について述べたが、比較的大 きい場合に関しても同様の展開が可能であり、これについては今後 報告していくつもりである。

\section{考考文献}

1) 日㯰興一郎，村上益美，山根一三 : ラチスアーチの幾何学的非線形性を考 虑した構面内弾性座屈について, 日本建築学会樓造系論文報告集, 第 397 号, pp.91-103, 1989 年 3 月

2) 上谷宏二, 桝井 健, 小林智弘：圈換連続体を用いた弾性删接トラスの座 屈後挙動解析法 その 1 その 3, 日本建築学会大会学術講演梗概集, pp.355-360, 1998 年 9 月

3）加藤史郎，石川浩一郎，横尾義貫 : 大スパントラス粠造物の耐㖘性に関す る研究 上下地震動を受ける平行弦トラスばりの耐辰性について, 日本 建築学会棈造系睔文報告集，第 360 号,pp.64-74,1986 年 2 月

4）加藤史郎, 石川浩一郎 : ピン接合単層ラチスドームの弾塑性座届荷重につ いて, 日本建築学会棈造系睔文報告集, 第 404 号, pp.105-114, 1989 年 10 月

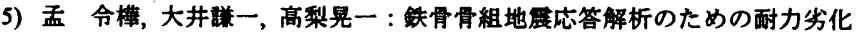
を伴う简易部材モデル, 日本建築学会樓造系論文報告集, 第 437 号, pp.115-124,1992 年 7 月

6) 山田 哲, 秋山 宏 : 局部座届を伴う銅部材の挙動に立脚した多層骨組の 弾塑性応答解析，日本建築学会権造系論文集，第 463 号, PP.125-133, 1994 年 9 月

7) 弾望性問題へ適用した例として，J. C. Simo, J. W. Ju : Strain- and Stress-Based Continuum Damage Models-I. Formulation, Int. J. Solids Structures, Vol.23, No.7, pp.821-840, 1987

8) J. C. Simo : Algorithms for Static and Dynamic Multiplicative Plasticity that Preserve the Classical Return Mapping Schemes of the Infinitesimal Theory, Comp. Methods Appl. Mech. Eng., Vol.99, No.1, pp.61-112, 1992

9) W. T. Koiter : Stress-Strain Relations, Uniqueness and Variational Theorems for Elastic-Plastic Materials with a Singular Yield Surface, Quart. Appl. Math., Vol.11, No.3, pp.350-354, 1953

10) J. C. Simo, J. G. Kennedy and S. Govindjee : Non-Smooth Multisurface Plasticity and Viscoplasticity. Loading/Unloading Conditions and Numerical Algorithms, Int. J. Numer. Methods Eng., Vol.26, pp.2161-2185, 1988

11) 元結正次郎，大塚贵弘：塑性論に基つくトラス梁の弾望性問題に対する解 析手法の提案, 日本建築学会構造系踚文集, 第 538 号, pp.109-114, 2000 年 12 月

12) 元結正次郎, 大塚贵弘 : トラス要素における弾塑性座届举動評価手法に関 する研究, 構造工学論文集, Vol.47B, pp.603-610, 2001 年 3 月

13) 大塚贵弘，元結正欧郎：塑性論に基つくトラス梁の弾塑性問題に対する解 析手法の提案 その 2 : 個材座屈を伴う埸合, 日本建築学会大会学術講演 梗概集, pp.909-910,2000 年 9 月 